\title{
PERSEPSI CALON GURU TERHADAP MODEL E-ASSESSMENT DALAM PEMBELAJARAN FISIKA
}

\author{
Hairunisyah Sahidu ${ }^{1^{*}}$, Gunawan ${ }^{1}$, dan Lovy Herayanti ${ }^{2}$ \\ ${ }^{1}$ Program Studi Pendidikan Fisika, Universitas Mataram \\ ${ }^{2}$ Program Studi Pendidikan Fisika, IKIP Mataram \\ *Email: hairunisyahsahidu@unram.ac.id
}

DOI: http://dx.doi.org/10.29303/jpft.v5i1.1164

\begin{abstract}
Assessment is an essential part of learning. The success of a lesson can be known from the results of the assessment carried out both in aspects of the process and product. Some problems related to conventional assessments have to find the right solution. One of them is through the use of computer technology in assessment, which can be used both online and offline in a model better known as e-assessment. The final goal of this research is to produce an e-assessment model that is oriented to the thinking ability of the physics teacher candidates. This research includes development research, using the DDD-E model, namely: decide, design, develop, and evaluate. This article discusses the responses of students and lecturers to the models that have been developed. Respondents gave a positive response to the development of this model. Student responses are at intervals of $86 \%$ to $94 \%$, with excellent categories. This model has the opportunity to continue to be developed for evaluation effectively and efficiently.
\end{abstract}

Keywords: e-assessment, pre-service physics teachers; Moodle

PENDAHULUAN

Asesmen atau penilaian merupakan kegiatan yang tidak dapat dipisahkan dengan sebuah pembelajaran. Melalui kegiatan asesmen dikumpulkan informasi tentang proses, produk, maupun sikap terhadap sebuah pembelajaran. Informasi yang dikumpulkan selanjutnya digunakan untuk membuat keputusan baik tentang individu maupun kelompok yang terlibat dalam proses pembelajaran. Secara lebih komprehensif, asesmen didefinisikan sebagai suatu proses atau kegiatan yang sistematis dan berkesinambungan untuk mengumpulkan informasi tentang proses dan hasil belajar peserta didik dalam rangka membuat keputusan-keputusan berdasarkan kriteria dari pertimbangan tertentu.

Jika ditinjau dari aspek kebermaknaan dalam proses pendidikan, penilaian berfungsi sebagai (1) penyeleksi, yaitu diperolehnya informasi tentang berhasil tidaknya peserta didik belajar, lulus tidaknya peserta didik dalam ujian, naik atau tidaknya peserta didik ke tingkat berikutnya, dan diberi tidaknya penghargaan. (2) alat diagnostik, yaitu deteksi adanya kesulitan belajar, deteksi adanya kelemahan dalam belajar, dan deteksi kenormalan mental peserta didik. (3) dasar penempatan (placement), seperti dasar membagi kelas, dasar penentuan penerima beasiswa atau penghargaan, atau penentuan pembagian kelompok. (4) pengukur keberhasilan, yaitu keberhasilan guru dalam membimbing, keberhasilan dalam belajar bagi peserta didik, keberhasilan program lembaga, dan keberhasilan pendidikan secara umum (Supriyadi, 2005; Sahidu \& Gunawan, 2019).

Beberapa masalah yang umumnya ditemukan terkait penilaian, antara lain: kualitas instrumen yang rendah, tidak sesuainya aspek yang diukur dengan tujuan penilaian, kontrol yang rendah selama proses penilaian berlangsung, lamanya proses rekapitulasi dan analisis data, tidak transparannya proses penilaian yang dilaksanakan, unsur subyektivitas yang masih tinggi, hingga umpan balik yang lambat dan tidak tepat sasaran. Beberapa masalah tersebut dapat diatasi dengan 
memperbaiki kualitas instrumen dan perangkat penilaian, sedangkan masalah lainnya dapat diatasi dengan menggunakan mekanisme asesmen secara online, yang kemudian lebih dikenal dengan sebutan $e$ assessment. Finkelstein et al. (2005), mengatakan bahwa komputer dapat digunakan untuk menunjang pelaksanaan pembelajaran fisika baik untuk mengumpulkan data, menyajikan, dan mengolah data. Mashami \& Gunawan (2018) menyatakan bahwa penggunaan komputer dalam pembelajaran dapat membantu dalam melatih keterampilan berpikir peserta didik, termasuk dalam $e$ assessment.

E-assessment adalah penggunaan teknologi informasi untuk kegiatan penilaian yang terkait. Kemampuan kognitif dinilai dengan menggunakan software $e$ assessment, sementara kemampuan praktis yang dinilai menggunakan e-portofolio atau software simulasi. Garrison \& Vaughan (2008) menyatakan bahwa dalam pembelajaran dan penilaian online terdapat beberapa keuntungan, diantaranya rekonseptualisasi dan redesain pembelajaran sehingga lebih menyegarkan (fresh), kemampuan mengatur konten lebih banyak, serta dapat menjadikannya sebagai sebuah komunitas inkuiri.

Penilaian online menggunakan teknologi elektronik untuk melakukan penilaian belajar peserta didik. Penilaian elektronik harus melibatkan kurikulum, $e$ learning, dan teknologi serta bersifat fleksibel dan mendukung penilaian berpikir tingkat tinggi, keterampilan sosial, dan kerja sama kelompok. Booth et al. (2003), menyebutkan bahwa penggunaan lingkungan online untuk mendukung pembelajaran dan peluang penilaian sebaiknya dilakukan dengan selfassessment, peer assessment, dan group/collaborative assessment.
Dalam artikel ini dibahas tanggapan mahasiswa calon guru fisika yang terlibat sebagai pengguna e-assessment yang telah dikembangkan dan diujicobakan dalam evaluasi proses dan hasil perkuliahan.

\section{METODE PENELITIAN}

Penelitian ini termasuk jenis penelitian dan pengembangan. Secara umum penelitian dilakukan dalam 4 tahapan, DDD-E, yaitu: decide (tahap memutuskan), design (tahap mendesain), develop (tahap pengembangan), dan evaluate (tahap mengevaluasi). Subjek penelitian ini adalah mahasiswa pada Program Studi Pendidikan Fisika pada salah satu LPTK di Mataram. Respon mahasiswa diukur menggunakan beberapa cara, diantara menggunakan angket skala Likert, wawancara pada beberapa responden mahasiswa, maupun tanggapan dalam focus group discussion yang dilaksanakan di akhir sesi perkuliahan di akhir semester.

\section{HASIL DAN PEMBAHASAN}

A. Hasil

Pengembangan model menggunakan software Moodle 3.3 Pemilihannya didasarkan pada pertimbangan Moodle digunakan untuk membangun sistem pembelajaran berbasis web, fitur pada Moodle mendukung pengembangan eassessment yang memungkinkan pengguna dapat melakukan ujian jarak jauh.

Mahasiswa memberikan respon terhadap penerapan e-assessment. Respon tersebut di rekap pada Tabel 1 berikut.

Tabel 1. Rekapitulasi tanggapan mahasiswa terhadap e-e-assessment

\begin{tabular}{llc}
\hline No & \multicolumn{1}{c}{ Aspek Penilaian } & $\begin{array}{c}\text { Skor } \\
\text { Rata-rata }\end{array}$ \\
\hline 1 & $\begin{array}{l}\text { Menu, fitur, dan kelengkapan } \\
\text { perangkat lunak }\end{array}$ & 4.7 \\
\hline 2 & $\begin{array}{l}\text { Kemudahan login dan akses } \\
\text { perangkat lunak }\end{array}$ & 4.6 \\
\hline 3 & $\begin{array}{l}\text { Penggunaan bahasa yang jelas } \\
\text { dan mudah dimengerti }\end{array}$ & 4.7 \\
\hline
\end{tabular}




\begin{tabular}{lll}
\hline 4 & $\begin{array}{l}\text { Ketersediaan contoh soal, } \\
\text { gambar dan simulasi }\end{array}$ & 4.5 \\
\hline 5 & $\begin{array}{l}\text { Relevansi model e-assessment } \\
\text { terhadap tujuan pembelajaran }\end{array}$ & 4.5 \\
\hline 6 & $\begin{array}{l}\text { Kemampuan untuk mendorong } \\
\text { penemuan ide dan keterampilan } \\
\text { berpikir mahasiswa }\end{array}$ & 4.3 \\
\hline 7 & $\begin{array}{l}\text { Ketersediaan feedback dan } \\
\text { tindak lanjut }\end{array}$ & 4.6 \\
\end{tabular}

Berdasarkan Tabel 1 dapat dipahami bahwa keseluruhan indikator penilaian respon mahasiswa berapada pada rata-rata di atas 4 (tertinggi 5). Berdasarkan kategori skala likert maka seluruh indikator berada pada kategore sangat baik dengan pencapaian teringgi pada indikator 1 dan 3 (pencapaian 94\%) dan terendah pada indikator 6 dengan pencapaian $86 \%$.

Beberapa data kualitatif dari wawancara juga didapatkan untuk penguatan data yang diperoleh sebelumnya. Sesi juga dilakukan dengan FGD untuk diskusi terkait temuan-temuan menarik lainnya bersama mahasiswa pengguna dan perwakilan dosen Pembina matakuliah.

\section{B. Pembahasan}

Teknologi menawarkan langkahlangkah baru untuk menilai pembelajaran yang dapat menghasilkan sumber data yang kaya dan memperluas cara di mana pendidik memahami ketuntasan belajar dan efektivitas mengajarnya. Penggunaan teknologi informasi untuk meningkatkan proses penilaian meliputi: tes awal dan tes akhir, analisis diagnostik, pelacakan siswa, penggunaan rubrik, dukungan dan pengiriman penilaian otentik melalui pembelajaran berbasis proyek, koleksi artefak, dan agregasi data dan analisisnya (Vendlinski \& Stevens, 2002).

Penggunaan teknologi informasi untuk mendukung evaluasi pembelajaran fisika menimbulkan motivasi tersendiri baik bagi dosen maupun mahasiswa. Secara umum, dosen setuju penggunaan e- assessment untuk mendukung pembelajaran fisika, hanya perlu pertimbangan pada jenis instrumen evaluasinya dan berbagai kendala teknis lainnya yang terkait jaringan internet maupun listrik yang mungkin bisa mati saat tes berlangsung. Penggunaan jenis instrumen yang bervariasi dan pengontrolan tampilan soal juga diantara masukan yang disampaikan.

Mahasiswa justru memberikan lebih banyak informasi terkait e-assessment yang sudah mereka lalui. Sebagian besar mahasiswa setuju dengan cepatnya feedback yang diterima jika tes dilakukan secara online. Mahasiswa lainnya menyampaikan tegangnya suasana menjelang tes berakhir. Dalam model ini mahasiswa harus mengerjakan soal secara tepat waktu sesuai informasi yang ditampilkan di monitor sejak awal tes berlangsung. Sebagian mahasiswa lainnya menyatakan sangat terbantu dengan model ini untuk latihan secara mandiri sebelum ujian yang sebenarnya berlangsung di laboratorium komputer. Hal ini sesuai dengan penelitian Sahidu et al (2017) yang menemukan bahwa model e-assessment dapat digunakan oleh mahasiswa untuk mengevaluasi diri sendiri (mandiri).

Penggunaan asesmen berbasis web lebih menarik perhatian mahasiwa daripada penggunaan asesmen tradisional. Herayanti et al (2017) menyatakan bahwa mahasiswa lebih mudah dalam menggunakan asesmen berbasis web (Moodle) karena lebih sederhana, efisien dan efektif. Asesmen tradisional juga relatif lebih sulit daripada asesmen berbasis web, karena asesmen tradisional membutuhkan pengelolaan waktu yang lebih kompleks daripada asesmen berbasis web. Hal ini seperti kendala yang ditemukan oleh Irwan, Arsyad, dan Arafah (2018) yang kesulitan dalam mengelola waktu ketika menerapkan asesmen berbasis penilaian sikap secara tradisional (tes dan agket). 
Tabel 1 menunjukkan respon mahasiswa yang sangat positif terhadap penggunaan e-assessment dalam pembelajaran. Hal ini ditunjukkan tinggkat ketercapaian yang tinggi pada semua indikator penilaian. Indikator pertama, yaitu kualitas menu, fitur dan kelengkapan perangkat lunak mendapat skor rata-rata 4,7 dengan ketercapaian 94\% kategori sangat baik. indikator 2 yang menunjukkan kemudahan login dan akses e-assessmen mendapatkan skor rata-rata 4.6 dengan tingkat ketercapaian 92\% kategori sangat baik. indikator 3 yang menunjukkan kualitas penggunaan bahasa yang jelas dan mudah dimengerti mendapatkan skor rata-rata 4,7 dengan tingkat ketercapaian $94 \%$ kategori sangat baik. indikator 4 dan 5 masingmasing menunjukkan ketersediaan contoh soal gambar dan simulasi serta relevansi eassessment dengan tujuan pembelajaran mendapatkan skor rata-rata 4.5 dengan ketercapaian $90 \%$ kategori sangat baik. Indikator 6 (kemampuan e-asessment dalam mengakomodir pengembangan kemampuan pemecahan masalah) mendapatkan skor rata-rata 4.3 dengan ketercapaian $86 \%$ kategori sangat baik. Dan indikator terakhir yang menunjukkan kualitas feedback eassessment mendapatkan skor 4.6 ketercapaian $92 \%$ kategori sangat baik.

Setiap indikator respon mahasiswa menujukkan kategori sangat baik. indikatorindikator tersebut menunjukkan kualitas media yang telah sesuai ekspetasi dan harapan baik peneliti dan pengguna eassessment tersebut. Kualitas perangkat lunak baik dari sisi tampilan, bahasa, fitur, materi soal, feedback sampai kemampuan media dalam mengakomodasi pengembangan kemampuan-kemampuan berpikir tingkat tinggi, seperti kemampuan pencahan masalah sudah sangat baik. Mahasiswa memberikan respon yang baik terhadap kemampuan e-assessment dalam membimbing mereka untuk menemukan ide dan mengembangkan kemampuan berpikir tingkat tinggi. Hasil ini juga sesuai dengan beberapa penelitian yang menunjukkan bahwa media pembelajaran berbasis komputer mampu memberikan pengalaman yang baik dan mampu mengembangkan rangkaian keterampilan-keterampilan berpikir tingkat tinggi (Gunawan et al., 2017; Mashami \& Gunawan, 2018, Adawiyah et al., 2019).

Teknologi baru, seperti Web, video digital, suara, animasi, dan interaktivitas, menyediakan alat-alat yang dapat membuat desain penilaian dan implementasi yang lebih efisien, tepat waktu, dan canggih. Buzzetto \& Alade (2006) menyatakan bahwa penggunaan teknologi informasi dapat meningkatkan efisiensi dan efektivitas penilaian proses dan hasil belajar mengajar. Penggunaan ICT bisa mendukung proses penilaian yang biasa dilakukan secara tradisional dengan melakukan beberapa modifikasi pada mekanisme pelaksanaannya. Beberapa manfaat asesmen berbasis elektroik berdasarkan JISC (2010) adalah sebagai berikut: (a) Dialog dan komunikasi. Interaksi secara online melalui forum, blog, email dan suara dapat memperkaya umpan balik dan membantu memperjelas tujuan pembelajaran dan standar. Dalam hal ini waktu lebih efisien, bisa dilakukan darimana dan kapanpun; (b) kedekatan (immediacy) dan kontingensi (contingency), tes interaktif secara online dan alat-alat genggam (seperti perangkat suara dan ponsel yang tersambung ke internet) dapat digunakan oleh peserta didik sesuai kebutuhannya; (c) keaslian (authenticity), simulasi secara online dan teknologi video memungkinkan mahasiswa untuk berlatih keterampilan di dunia nyata dengan pengalaman untuk sukses atau gagal; (d) kecepatan dan kemudahan pengolahan data, pengiriman penilaian dan sistem manajemen dapat memberikan umpan balik instan baik untuk pelajar dan 
praktisi, menghasilkan informasi yang kuat untuk meninjau kurikulum dan proses penjaminan mutu; (e) self-regulated learning, dengan metode ini penilaian diri, pengumpulan bukti dan refleksi pada prestasi dalam portofolio dan blog dapat dilakukan sendiri dan mendorong pada kemampuan berpikir tingkat tinggi yang pada gilirannya meningkatkan kinerja; (f) nilai tambah (additionality) dan efisiensi (efficiency). Teknologi memungkinkan untuk menilai kemampuan dan proses yang sebelumnya sulit untuk diukur. Hal ini dapat menambah kualitas umpan balik, bahkan dalam konteks kelompok besar, akan lebih efisien dari sisi waktu yang digunakan untuk pelaksanaan hingga tindak lanjutnya.

Dalam penelitian yang dilakukan oleh Robles \& Braathen (2002) ditemukan bahwa penggunaan asesmen secara online efektif membantu mengukur tingkat pemahaman peserta didik. Teknik asesmen dalam perkuliahan tradisional dapat pula dimodifikasi untuk pelaksaan perkuliahan secara online. Penilaian secara online memiliki kelebihan dalam kemampuan mengukur tingkat pemahaman lebih banyak peserta didik. Dalam model pembelajaran tradisional, ketika seorang dosen bertanya, maka hanya akan ada satu mahasiswa berpeluang menjawab pada saat itu. Guru tidak dapat mengetahui jika ada siswa lain di kelas tersebut yang belum paham apa yang diajarkan. Ketika pertanyaan diberikan secara online, maka setiap siswa berpeluang memberikan jawaban pada saat yang sama sebelum meninggalkan ruang perkuliahan. Selain itu, juga bisa dilakukan analisis pada kemampuan komunikasi tulis setiap peserta, yang bisa menjadi salah satu indikator tingkat perkembangannya.

Tes berbasis website memiliki keuntungan signifikan pada biaya, kemudahan penggunaan, reliabilitas, peniruan, penskoran, hasil, dan manajemen data. Penilaian digital dapat mengukur dengan reliabilitas yang tinggi dan tidak ada subyektivitas saat mengolah data. Kendle \& Northcote (2000) menyatakan terdapat sepuluh kriteria sebagai petunjuk untuk mendesain dan mengembangkan asesmen online yang efektif, yang kemudian dimodifikasi menjadi enam (6) kriteria , yaitu: (1) Variety: menggabungkan beberapa metode, baik kualitatif maupun kuantitatif; (2) Authenticity: menggunakan tugas open-endedyang disimulasikan sebagai tugas kerja, serta tugas-tugas kuantitatif yang tepat; (3) Collaboration: memungkinkan untuk interaksi antara peserta didik dan orang lain, dan menggunakan teknologi komunikasi sesuai; (4) Feedback: memastikan mekanisme umpan balik yang sesuai yang mungkin menggunakan umpan balik rekan dan tutor sebaya; (5) Online resources: menggunakan semua paket secara penuh menggunakan semua sumber daya yang tersedia serta sumber informasi internet lainnya; (6) Learner responsibility: menyediakan pilihan dan kesempatan untuk akuntabilitas dalam penilaian tugas.

Sebuah sistem e-assessment memerlukan beberapa jenis aktivitas interaktif dan sebuah sistem yang memungkinkan mendorong peserta didik untuk menulis alasan atau memecahkan masalah yang diberikan. E-assessment saat ini menjadi dikenal dan lebih banyak digunakan. Ada beberapa keuntungannya dibandingkan penilaian tradisional menggunakan tes tertulis, diantaranya: biaya jangka panjang lebih rendah, umpan balik instan untuk peserta didik, fleksibilitas yang lebih besar pada lokasi dan waktu, meningkatkan reliabilitas, lebih adil dan tidak memihak (mesin tidak mengenal setiap peserta), efisiensi penyimpanan yang lebih besar, puluhan ribu naskah jawaban dapat disimpan pada server dibandingkan dengan ruang fisik yang diperlukan untuk kertas. Model-model pertanyaan yang 
muncul menggabungkan kreativitas dan interaktivitas dengan multimedia.Meskipun demikian, e-assessment juga memiliki kelemahan, diantaranya biaya yang mahal dalam pengembangannya, juga tidak cocok untuk setiap jenis penilaian seperti pertanyaan dengan jawaban yang lebih panjang dalam soal essay, atau pertanyaan tentang urutan/tahapan yang juga perlu dijelaskan kembali. Beberapa model asesmen formatif, ketika diadakan secara online, kemudian disebut asesmen formatif online. Begitupun dengan jenis yang lainnya, perubahan pada mekanisme pelaksanaan dari konvensional menjadi online akan mengalami penyesuaian dalam penyebutannya

\section{PENUTUP}

Dalam penelitian dan pengembangan ini telah berhasil dikembangkan model eassessment untuk mendukung perkuliahan fisika. Dalam pengujian yang telah dilaksanakan, beberapa fitur telah disempurnakan untuk pengujian skala yang lebih luas. Dosen dan mahasiswa memberikan respon yang positif terhadap pengembangan model ini. Respon mahasiswa menunjukkan ketercapaian yang sangat baik pada semua respon dengan tingkat keberhasilan antara $86 \%$ hingga 94\%. Model ini berpeluang untuk terus dikembangkan untuk evaluasi secara efektif dan efisien.

\section{REFERENSI}

Adawiyah, R., Harjono, A., Gunawan, G., \& Hermansyah, H. 2019. Interactive e-book of physics to increase students' creative thinking skills on rotational dynamics concept. In Journal of Physics: Conference Series. 1153 (1), p. 012117.

Booth, R. et al. 2003. The Development of Quality Online Assessment in
Vocational Education and Training Volume 1. Australia: NCVER.

Buzzetto-More, N. A., \& Alade, A. J. 2006. Best practices in e-assessment. Journal of Information Technology Education: Research, 5(1), 251-269.

Finkelstein, N. D., Adams, W. K., Keller, C. J., Kohl, P. B., Perkins, K. K., Podolefsky, N. S., ... \& LeMaster, R. 2005. When learning about the real world is better done virtually: A study of substituting computer simulations for laboratory equipment. Physical review special topics-physics education research, 1(1), 010103.

Garrison, D.R \& Vaughan, N.D., 2008. Blended Learning in Higher Education. San Fransisco: John Willey \& Sons, Inc.

Gunawan \& Liliasari, 2012. Model Virtual Laboratory Fisika Modern untuk Meningkatkan Disposisi Berpikir Kritis Calon Guru. Jurnal Ilmiah Cakrwala Pendidikan, LPPMP UNY. Juni 2012, Th. XXXI, No. 2.185- 199 .

Gunawan, Harjono, A., Sahidu, H., Herayanti, L. 2017. Virtual Laboratory of Electricity Concept to Improve Prospective Physics Teachers' Creativity. Jurnal Pendidikan Fisika Indonesia 13 (2), 102-111.

Gunawan, G., Harjono, A., Sahidu, H., \& Herayanti, L. 2017. Virtual Laboratory to Improve Students' Problem-Solving Skills on Electricity Concept. Jurnal Pendidikan IPA Indonesia,6(2), 257-264.

Herayanti, L., Fuaddunnazmi, M., \& Habibi, H. 2017. Pengembangan Perangkat Pembelajaran Fisika Berbasis Moodle. Jurnal Pendidikan Fisika dan Teknologi, 3(2), 197206.

Irwan, A., Arsyad, M., \& Arafah, K. 2018. Pengembangan Instrumen Penilaian 
Sikap Praktikum Fisika Dasar I

Pada Mahasiswa Jurusan

Pendidikan Fisika UIN Alauddin Makassar. Jurnal Pendidikan Fisika dan Teknologi, 4(2), 168-175.

Joint Information Systems Committee. 2010. Effective Assessment in a Digital Age. Higher Education Funding Council for England, Bristol.

Kendle, A., \& Northcote, M. 2000. The struggle for balance in the use of quantitative and qualitative online assessment tasks. In Ascilite (Vol. 2002).

Mashami, R. A., \& Gunawan, G. 2018. The Influence of Sub-Microscopic Media Animation on Students' Critical Thinking Skills Based on Gender. In Journal of Physics: Conference Series. 1108 (1), p. 012106.

Robles, M., \& Braathen, S. 2002. Online assessment techniques. Delta Pi Epsilon Journal, 44(1), 39-49.

Sahidu, H., Gunawan, Indriaturrahmi, I., \& Astutik, F. 2017. Desain Sistem EAssessment pada Pembelajaran Fisika di LPTK. Jurnal Pendidikan Fisika dan Teknologi, 3(2), 265270.

Sahidu, H., \& Gunawan, G. 2019. Evaluasi Pendidikan Abad 21. Mataram: Arga Puji Press

Supriyadi. 2005. Kajian Penilaian Pencapaian Hasil Belajar Fisika. Malang: UM Press

Vendlinksi, T., \& Stevens, R. 2002. Assessing student problem-solving skills with complex computer-based tasks. The Journal of Technology, Learning and Assessment, 1(3), 120. 